\title{
Effects of Dietary Supplementation with Rapeseed and Linseed Oil on the Composition of Fatty Acids in Porcine Muscle Tissue
}

\author{
Gordana Kralik ${ }^{1}$, Vladimir Margeta ${ }^{1}$, Pavel Suchý2, Eva Straková2 \\ ${ }^{1}$ Faculty of Agriculture, Josip Juraj Strossmayer University of Osijek, Croatia \\ ${ }^{2}$ Faculty of Veterinary Hygiene and Ecology, University of Veterinary and Pharmaceutical Sciences Brno, \\ Czech Republic
}

Received May 15, 2009

Accepted September 21, 2010

\begin{abstract}
The objective of this study was to determine the effects of dietary supplementation with rapeseed and linseed oils on changes of the fatty acid profile in porcine meat. The research was conducted on 45 fattening pigs divided into three groups. Group 1 was given a diet with $2 \%$ of sunflower oil, group 2 was given a diet with $2 \%$ of rapeseed oil and group 3 was given a diet supplemented with $2 \%$ of linseed oil. The highest content of n-3 polyunsaturated fatty acids (PUFA) and the most favourable ratio of n-6/n-3 PUFA was determined in the meat of pigs that were fed diets with linseed oil $(P<0.001)$, whereas the meat of pigs that were fed diets with sunflower oil had an unfavourable ratio of these acids. The results point out the necessity of finding out optimal portions of forages rich in PUFA to improve the ratio of fatty acids in porcine muscle tissue.
\end{abstract}

Pigs, fatty acids, PUFA, n-6/n-3 ratio

The content and composition of saturated and polyunsaturated fatty acids in human nutrition is important for human health protection. A high content of saturated fatty acids (SFA) contained in food, and an unfavourable ratio of n-6 and n-3 polyunsaturated fatty acids (PUFA) can be a cause of many cardiovascular diseases. Porcine meat contains significant amounts of fatty acids and it has an unfavourable ratio of n-6/n-3 PUFA (Enser et al. 1996). This unfavourable ratio is due to feeding pigs with crops rich in linoleic acid $(18: 2 n-6)$. Recent research has been aimed at improving the $n-6 / n-3$ ratio in porcine muscle and fatty tissue in order to assure a potentially inexpensive source of polyunsaturated fatty acids in human nutrition. The most important polyunsaturated fatty acids are $\alpha$-linolenic (8:3n-3), eicosapentaenoic (EPA, 22:5n-3) and docosahexaenoic (DHA, 22:6n-3). Saturated and unsaturated fatty acids are synthesized in vivo in a porcine organism, however, some of them, such as linoleic and linolenic acids (18:3n-3) cannot be synthesized in the organism and need to be taken in through diets. The composition and ratio of fatty acids in porcine meat can be altered by dietary supplementation with forages that are poor in n-6 PUFA and rich in n-3 PUFA (Nürnberg et al. 2005; Kouba 2006; Kušec et al. 2008). However, there are some limitations to the modification of the fatty acid profile in porcine meat, as the increased content of PUFA can negatively influence nutritional and sensory quality of meat (Wood et al. 2003; Kušec et al. 2008). It is important to determine to what extent the fatty acid profile in porcine muscle tissue can be altered without affecting its nutritional and sensory characteristics. Beside dietary intake, the fatty acid profile and the n-6/n-3 ratio in porcine meat can be altered also by molecular-genetic methods, such as cloning, producing transgenic pigs that have a considerably higher content of n-3 fatty acids in muscle and fatty tissue and a considerably lower n-6/n-3 ratio (Lai et al. 2006). Moreover, it should be also emphasized that the content of saturated and unsaturated fatty acids in porcine lipids depends on many other factors, such as age, sex or stress sensitivity status. The objective of the present research was to determine to what extent rapeseed and linseed oils

Address for correspondence:

Prof. Dr.Sc. Dr.h.c. Gordana Kralik

Faculty of Agriculture

Josip Juraj Strossmayer University of Osijek

Trg svetog Trojstva 3, 31000 Osijek, Croatia

Phone: +38531224241

E-mail: gkralik@pfos.hr

http://www.vfu.cz/acta-vet/actavet.htm 
supplemented to porcine diets affect the proportion of muscle tissue in porcine carcasses, and the change of fatty acid profile in porcine muscle tissue.

\section{Materials and Methods}

The research was carried out on 45 fattening pigs of three-way crossbreeds of Large White, German Landrace and Pietrain. Pigs were divided into three groups of 15 pigs and fed standard diets containing $15.6 \%$ of crude protein and 13.7 MJ/ME (Table 1). For the purpose of carrying out the research, group 1 (control) was fed a diet supplemented with $2 \%$ of sunflower oil, group 2 was fed a diet with $2 \%$ of rapeseed oil instead of sunflower oil, and group 3 was fed a diet supplemented with $2 \%$ of linseed oil. The oils were dosed into diets using a special device in the factory. As an antioxidant, Oxy-Tectst was used at the total amount of $25 \mathrm{mg} / \mathrm{kg}$ of feed.

Table 1. Major nutrients of experimental diets $(\mathrm{g} / \mathrm{kg})$ in the three groups of pigs

\begin{tabular}{|l|c|c|c|c|c|c|}
\hline Group & $\begin{array}{c}\text { Crude } \\
\text { protein }\end{array}$ & $\begin{array}{c}\text { Crude } \\
\text { fat }\end{array}$ & $\begin{array}{c}\text { Crude } \\
\text { fibre }\end{array}$ & $\begin{array}{c}\text { Crude } \\
\text { ash }\end{array}$ & Calcium & Phosphorus \\
\hline 1 & 176.12 & 50.76 & 33.51 & 47.74 & 6.48 & 4.85 \\
\hline 2 & 172.25 & 38.06 & 30.66 & 46.24 & 6.36 & 4.74 \\
\hline 3 & 172.75 & 43.34 & 31.25 & 44.95 & 6.35 & 5.07 \\
\hline
\end{tabular}

The linseed oil was obtained from crushed flax seeds. A fat source was added to porcine diets in the last fattening phase (from approximately $70 \mathrm{~kg}$ until the approximate slaughter weight of $100 \mathrm{~kg}$ ). At the end of fattening period, the pigs were slaughtered in a slaughter house. The content of fatty tissue in $\mathrm{m}$. longissimus dorsi was determined by the method of Soxhlet, and the content of fatty acids in lipids was determined using the Chrompack CP-9000 chromatograph. Percentages of fatty acids in diets and muscle tissue were determined by the method of Csapo et al. (1986).

Digestion and fat extraction

Homogenized samples were weighed (containing about 0.5-1 g fat) into an Erlenmeyer flask, 8-20 ml of concentrated hydrochloric acid was added and the mixture was boiled in a steam-bath for 60-90 min. Then samples were cooled down and $7 \mathrm{ml}$ of ethanol was added followed by $25 \mathrm{ml}$ of diethylether, and samples were shaken again vigorously for $1 \mathrm{~min}$. After that, $25 \mathrm{ml}$ of petrolether was added (b.p. $<60^{\circ} \mathrm{C}$ ) and the samples were shaken for $1 \mathrm{~min}$. When the two phases were separated, about $20 \%$ of the organic phase was poured (containing about 150-200 mg fat) into a round-bottom flask and evaporated under vacuum on a Rotadest. Complete evaporation was not required.

\section{Hydrolysis and esterification}

Four $\mathrm{ml}$ of $0.5 \mathrm{M}$ sodium-hydroxide in methanol were added to a round-bottom flask mounted on a cooler and boiled in a water bath until the fat droplets disappeared. Then $4 \mathrm{ml}$ of $14 \%$ boron-trifluoride in methanol were added through the cooler and boiled for $3 \mathrm{~min}$. Then 2-6 $\mathrm{ml}$ of $\mathrm{n}$-hexane were added and boiled for $1 \mathrm{~min}$ and cooled down. The level of the organic phase was brought to the neck of the flask with saturated sodium-chloride solution. When phases were separated, samples for analyses from the organic phase were taken and dried on sodium-sulphate.

Gas chromatography

Instrument: Chrompack CP 9000; column: $100 \mathrm{~mm} \times 0.25 \mathrm{~mm}$ wall coated open tubular (WCOT); stationary phase: CP-SIL 88 (FAME); detector: flame ionization detector (FID); injector: splitter; gases: carrier gas: helium, $235 \mathrm{kPa}$; at the detector: air: $250 \mathrm{~cm}^{3} \cdot \mathrm{min}^{-1}$, hydrogen: $30 \mathrm{~cm}^{3} \cdot \mathrm{min}^{-1}$, helium: $30 \mathrm{~cm}^{3} \cdot \mathrm{min}^{-1}$; temperatures injector: $270{ }^{\circ} \mathrm{C}$; detector: $270{ }^{\circ} \mathrm{C}$; column: $140^{\circ} \mathrm{C}(10 \mathrm{~min}), 10^{\circ} \mathrm{C} \cdot \mathrm{min}^{-1}$ increase up to $235^{\circ} \mathrm{C}(26 \mathrm{~min})$; injected volume: $0.5 \mu 1$.

Research results were analysed by SAS statistics program Ver. 6.12. Data were analyzed by statistical software Statistica 7.1.

\section{Results and Discussion}

The results of the analysis of the fatty acid content in porcine diets are presented in Table 2. Compared to diets that contained sunflower oil and linseed oil, the diet that contained rapeseed oil had a significantly higher content $(P<0.001)$ of monounsaturated fatty acids (MUFA). The content of n-6 PUFA was the highest in the diet supplemented with sunflower oil $(P<0.001)$, and the content of n-3 PUFA was the highest in the diet containing linseed oil $(P<0.001)$. The $n-6 / n-3$ PUFA ratio was the highest in the diet containing sunflower oil, and the lowest in the diet with linseed oil $(P<0.001)$. 
Table 2 . Fatty acid contents of diets (\% in total fatty acids) in the three groups of pigs

\begin{tabular}{|c|c|c|c|}
\hline \multirow{2}{*}{ Fatty acid } & \multicolumn{3}{|c|}{ Group } \\
\hline & 1 & 2 & 3 \\
\hline Caprinic acid, 10:0 & 0.00 & 0.01 & 0.00 \\
\hline Lauric acid, 12:0 & 0.01 & 0.02 & 0.00 \\
\hline Myristic acid, 14:0 & 0.16 & 0.15 & 0.18 \\
\hline Pentadecanoic acid, 15:0 & 0.06 & 0.07 & 0.08 \\
\hline Palmitic acid, 16:0 & 16.66 & 14.58 & 17.25 \\
\hline Heptadecanoic acid, 17:0 & 0.10 & 0.11 & 0.11 \\
\hline Stearic acid, $18: 0$ & 3.16 & 2.62 & 3.03 \\
\hline Behenic acid, 22:0 & 0.55 & 0.40 & 0.34 \\
\hline Lignoceric acid, 24:0 & 0.22 & 0.17 & 0.13 \\
\hline SFA & 20.92 & 18.13 & 21.13 \\
\hline Palmitoleic acid, 16:1 & 0.12 & 0.19 & 0.12 \\
\hline Elaidic acid, $18: \ln 9 \mathrm{t}$ & 0.48 & 0.64 & 0.58 \\
\hline Oleic acid, 18:1n9c & 23.06 & 33.90 & 21.15 \\
\hline Eicosenoic acid, 20:1 & 0.29 & 0.59 & 0.34 \\
\hline Erucic acid, 22:1 & 0.21 & 0.25 & 0.26 \\
\hline MUFA & $24.16^{B}$ & $35.57^{A}$ & $22.45^{B}$ \\
\hline Linoleic acid, 18:2n6 & 47.28 & 33.97 & 34.48 \\
\hline$\gamma$-Linoleic acid, 18:3n6 & 0.02 & 0.06 & 0.12 \\
\hline Eicosadienoic acid, 20:2n6 & 0.04 & 0.06 & 0.05 \\
\hline Eicosatrienoic acid, 20:3n6 & 0.10 & 0.11 & 0.14 \\
\hline n-6 PUFA & $47.44^{A}$ & $34.20^{B}$ & $34.79^{B}$ \\
\hline$\alpha$-Linolenic acid, 18:3n3 & 1.12 & 5.71 & 14.44 \\
\hline Eicosatrienoic acid, 20:3n3 & 0.06 & 0.07 & 0.06 \\
\hline Docosapentaenoic acid, 22:5n3 & 0.00 & 0.16 & 0.57 \\
\hline n-3 PUFA & $1.18^{A, B}$ & $5.94^{B}$ & $15.07^{A}$ \\
\hline n-6 / n-3 PUFA & $40.31^{A}$ & $5.75^{B}$ & $2.31^{A, B}$ \\
\hline Unidentified (A-E) & 6.31 & 6.32 & 7.14 \\
\hline
\end{tabular}

MUFA - monounsaturated fatty acids, PUFA - polyunsaturated fatty acids, SFA - saturated fatty acids

$\mathrm{A}, \mathrm{B}=P<0.001$

to porcine diets significantly increased the content of linolenic acid and other long-chain $\mathrm{n}-3$ acids in porcine muscle and fatty tissue, at the same time decreasing the portion of arachidonic acid. The fat component in feed can influence not only the fatty acid ratio but also sensory and technological properties of fat and muscle. A higher proportion of unsaturated fatty acids can have a negative influence on technological properties of fat and muscle and their oxidative stability. The authors also stated that oxidative stability of muscle lipids was reduced in pigs that were fed diets with linseed oil as compared to pigs fed diets without linseed oil. Meadus et al. (2009) mentioned problems with odour and flavour in bacon enriched with polyunsaturated fatty acids. On the other hand, Matthews et al. (2000) reported that feeding the whole linseed had no negative effect on the oxidative stability of the porcine meat. Rey et al. (2004) also stated that supplementation of linseed oil to porcine diets resulted in the increase of eicosapentaenoic acid (EPA) and docosahexaenoic acid (DHA) in neutral lipids and in the decrease of n-6/n-3 ratio. Pieszka (2007) pointed out that pigs fed sunflower oil had the highest n- $6 / n-3$ ratio of polyunsaturated fatty acids in muscle tissue lipids compared to pigs fed linseed, palm and rapeseed oils, and that supplementation of different oils in diets did not have a significant effect on the content of total cholesterol in 
Table 3. Portions of fatty acids (\%) in total fatty acids in muscle tissue of pigs

\begin{tabular}{|c|c|c|c|}
\hline \multirow{2}{*}{ Fatty acid } & \multicolumn{3}{|c|}{ Group } \\
\hline & 1 & 2 & 3 \\
\hline Caprinic acid, 10:0 & 0.06 & 0.07 & 0.08 \\
\hline Lauric acid, 12:0 & 0.06 & 0.08 & 0.06 \\
\hline Myristic acid, 14:0 & 1.16 & 1.08 & 1.10 \\
\hline Pentadecanoic acid, 15:0 & 0.05 & 0.07 & 0.06 \\
\hline Palmitic acid, 16:0 & 23.97 & 23.44 & 23.41 \\
\hline Heptadecanoic acid, 17:0 & 0.31 & 0.45 & 0.33 \\
\hline Stearic acid, $18: 0$ & 13.16 & 13.15 & 13.71 \\
\hline Behenic acid, 22:0 & 0.14 & 0.16 & 0.14 \\
\hline Tricosanoic acid, 23:0 & 0.03 & 0.05 & 0.11 \\
\hline Lignoceric acid, 24:0 & 0.09 & 0.11 & 0.12 \\
\hline SFA & 39.06 & 38.65 & 39.12 \\
\hline Palmitoleic acid, 16:1 & 0.02 & 0.02 & 0.02 \\
\hline Elaidic acid, 18:1n9t & 2.95 & 2.53 & 2.70 \\
\hline Oleic acid, $18: \ln 9 \mathrm{c}$ & 0.33 & 0.40 & 0.34 \\
\hline Eicosenoc acid, 20:1 & 37.30 & 35.20 & 37.42 \\
\hline Erucic acid, $22: 1$ & 0.59 & 0.59 & 0.62 \\
\hline MUFA & 41.20 & 38.75 & 41.10 \\
\hline Linoleic acid, 18:2n6 & 13.64 & 15.06 & 11.10 \\
\hline$\gamma$-Linoleic acid, 18:3n6 & 0.07 & 0.08 & 0.06 \\
\hline Eicosadienoic acid, 20:2n6 & 0.41 & 0.45 & 0.32 \\
\hline Eicosatrienoic acid, 20:3n6 & 0.50 & 0.54 & 0.43 \\
\hline Arachidonic acid, 20:4n6 & 2.90 & 3.45 & 2.65 \\
\hline n-6 PUFA & 17.52 & $19.58^{A}$ & $14.56^{B}$ \\
\hline$\alpha$-Linoleic acid, 8:3n3 & 0.18 & 0.44 & 1.01 \\
\hline Eicosapentaenoic acid, 20:5n3 & 0.03 & 0.06 & 0.10 \\
\hline Docosapentaenoic acid, $22: 5 \mathrm{n} 3$ & 0.21 & 0.34 & 0.32 \\
\hline Docosahexaenoic acid, $22: 6 \mathrm{n} 3$ & 0.02 & 0.06 & 0.06 \\
\hline n-3 PUFA & $0.44^{A, B}$ & $0.90^{B}$ & $1.49^{4}$ \\
\hline n-6 / n-3 PUFA & $40.61^{A}$ & $22.17^{B}$ & $9.92^{A, B}$ \\
\hline Unidentified (A-E) & 1.87 & 2.24 & 3.87 \\
\hline
\end{tabular}

MUFA - monounsaturated fatty acids, PUFA - polyunsaturated fatty acids, SFA - saturated fatty acids

$\mathrm{A}, \mathrm{B}=P<0.001$ muscle tissue. Compared to dietary supplementation with rapeseed oil, Mitchaothai et al. (2008) stated that dietary supplementation of sunflower oil affected significantly greater deposition of saturated fatty acids (SFA) in porcine muscle lipids, which was not the case with MUFA and PUFA. However, the authors did not determine significant differences in sensory and qualitative traits of porcine muscle tissue.

Based on our results, it can be concluded that standard diets fed to pigs had an unfavourable content and ratio of saturated and polyunsaturated fatty acids. Diets supplemented with sunflower oil had the highest content of MUFA, while diets with linseed oil contained the most PUFA and had the lowest $n 6 / \mathrm{n} 3$ ratio. The highest content of n-3 PUFA and the most favorable $n-3 / n-6$ PUFA ratio was determined in the muscle tissue of pigs fed diets with linseed oil. The results point out the necessity to further investigate optimal proportions of forages rich in n-3 PUFA for improving the fatty acid profile in porcine muscle tissue, and their impact on oxidative stability and sensory characteristics of porcine fat and muscle.

\section{References}

Csapó J, Husvéth F, Csapó-Kiss ZS, Varga-Visi É, Horn P 2000: Fatty acid composition and cholesterol content of the fat of pigs of various genotypes. Agriculture 6: 64-67

Dugan MER, Aalhus JL, Robertson WM, Gibson LL, Rolland DC, Larsen IL 2004: Feeding flax seed to pigs. Effects on pork fatty acids composition and palatability. Adv Pork Prod 15: Abstract 14

Enser M, Hallett K, Hewett B, Fursey GAJ, Wood JD 1996: Fatty acid content and composition of English beef, lamb and pork at retail. Meat Sci 42: 443-456

Kouba M 2006: Effect of dietary omega-3 fatty acids on meat quality of pigs and poultry. Omega 3 Fatty Acids Research. Nova Publishers New York, pp. 225-239

Kušec G, Kralik G, Margeta V, Durkin I, Hanžek D 2008: Effect of dietary rapeseed oil on pig meat quality traits. Krmiva 50: $95-100$

Liangxue L, Jing XK, Rongfeng L, Jingdong W, William TW, Hwan YY, Yanhong H, Wax DM, Murphy CN, Rieke A, Samuel M, Linville ML, Korte SW, Evans RW, Starzl TE, Prather RS, Dai Y 2006: Generation of cloned transgenic pigs rich in omega-3 fatty acids. Nat Biotechnol 24: 435-436

Matthews KR, Homer DB, Thies F, Calder PC 2000: Effect of whole linseed (Linum usitatissimum) in the diet of finishing pigs on growth performance and on the quality and fatty acid composition of various tissues. Br $\mathrm{J}$ Nutr 83: 637-643 
Meadus WJ, Duff P, Uttaro B, Aalhus JL, Rolland DC, Gibson LL, Dugan ME 2009: Production of docosahexaenoic acid (DHA) enriched bacon. J Agricult Food Chem 5118-5120

Mitchaothai J, Everts H, Yuangklang C, Wittayakun S, Vasupen K, Wongsuthavas S, Srenanul P, Hovenier R, Beynen AC 2008: Digestion and deposition of individual fatty acids in growingfinishing pigs fed diets containing either beef tallow or sunflower oil. J Anim Phys Anim Nutr 92: 502-510

Nürnberg K, Dannenberger D, Nuernberg G 2005: Effect of grass-based and a concentrate feeding system on meat quality characteristic and fatty acid composition of longissimus muscle in different cattle breed. Livest Prod Sci 94: 137-147

Nuernberg K, Fischer K, Nuernberg G, Kuechenmeister U, Klosowska D, Eliminowska-Wenda G, Fiedler I, Ender K 2005: Effects of dietary olive and linseed oil on lipid composition, meat quality, sensory characteristics and muscle structure in pigs. Meat Sci 70: $63-74$

Pieszka M 2007: Effect of vegetable oils supplementation in pig diets on lipid oxidation and formation of oxidized forms of cholesterol in meat. Pol J Food Nutr Sci 57: 245-258

Rey A, Lopez-Bote CJ, Kerry JP, Lynch PB, Buckley DJ, Morrissey PA 2004: Modification of lipid composition and oxidation in porcine muscle and muscle microsomes as affected by dietary supplementation of n-3 with either n-9 or n-6 fatty acids and alpha-tocopheryl acetate. Ani Feed Sci Technol 113: 1-4

Wood JD, Richardson RI, Nute GR, Fisher AV, Campo MM, Kasapidou E 2003: Effects of fatty acids on meat quality: a review. Meat Sci 66: 21-32 
